\title{
First record of the non-native copepod Pseudodiaptomus trihamatus Wright, 1937 (Copepoda, Calanoida) in Rio de Janeiro state, Brazil.
}

\author{
G. M. Rocha ${ }^{a}$, J. C. Féres ${ }^{a}$, B. S. Esteves ${ }^{b}$ and J. M. Sterza ${ }^{a}$ \\ ${ }^{a}$ Ethica Ambiental Serviços e Consultoria Ltda., Rua Anésio Alvarenga, 276, Praia da Costa, \\ CEP 29101-230, Vila Velha, ES, Brasil \\ 'Porto do Açu Operações S.A., Fazenda Saco Dantas, s/n, São João da Barra, CEP 28200-000, Rio de Janeiro, RJ, Brasil \\ *e-mail: gusmrocha@uol.com.br
}

Received: August 10, 2017 - Accepted: October 27, 2017 - Distributed: May 31, 2019

(With 2 figures)

Pseudodiaptomus trihamatus Wright, 1937 is originally from Indo-pacific coast (Walter, 1984) and was introduced in Brazil in 1977. Its distribution in northeastern Brazilian territory is documented on different papers (Medeiros et al., 1991, 2006; Ferreira et al., 2009; Santos et al., 2009; Almeida et al., 2012). These studies point out the importance of monitoring the expansion scenario of this species.

This note presents the first record of $P$. trihamatus in southeastern Brazilian coast (Rio de Janeiro state), handing an updated scenario of its distribution and helping understand its environmental requirements for dispersion and establishment in new environments.

The occurrence of $P$. trihamatus was observed in October 2015 in a plankton sample from Açu lagoon, located between Campos dos Goytacazes and São João da Barra Municipalities, Rio de Janeiro state, during biological surveys carried out for two years. We filtered $200 \mathrm{~L}$ using $50 \mu \mathrm{m}$ plankton net and fixed with $4 \%$ formalin solutions. Salinity was measured by a portable Hanna Multiparameter.

Açu lagoon has a 10 kilometer extension parallel to shoreline and it is strongly influenced by coastal waters due to artificial connections to ocean, marine water percolation and marine spray (Chagas and Suzuki, 2005). As a consequence, water salinity reaches 43.2 (Sterza et al., 2002).

General view and taxonomic features of the collected P. trihamatus specimens are shown in Figures 1A-E (female) and Figures 2A, B (male). Both specimens presents all taxonomic characteristics that describes this species, however, the number of spinules on the female left posterodorsal margin of the Urosome differs. The female collected in this study presents three spinules (see Figure 1C) and not two, as registered by the taxonomic description of this species (Walter, 1984; Walter et al., 2006).

Pseudodiaptomus trihamatus is the only species among Pseudodiaptomus that presents registered occurrence and even indications of reproduction activity in salinity over 42, (even up to 70) in Brazilian waters (see Medeiros et al., 2006; Matsumura-Tundisi and Tundisi, 2007 for the Genus salinity range of occurrence in Brazil). This species can also occur in freshwaters (Oka et al., 1991). Therefore, its tolerance to a wide salinity range makes it extremely competitive in comparison to native species, increasing dispersal and adaptation potential. It is well known that non-native Pseudodiaptomus may cause changes in native plankton communities, replacing species of the same Genus (Cordell et al., 2008).

During our surveys at Açu lagoon, salinity was 24.81 on average, with a peak of 74 in September 2015, one month earlier than $P$. trihamatus registration. Density was 10 ind. $/ \mathrm{m}^{3}$ on October 2015 (see Table 1), similar to previously found in other study in Brazil (Almeida et al., 2012).

Pseudodiaptomus copepodits presented 120 ind. $/ \mathrm{m}^{3}$ in the same month as $P$. trihamatus adults. Thus, despite the absence of female carrying eggs in the samples, $P$. trihamatus could present reproductive potential at Açu lagoon. Those copepodits could also be from the native P. acutus. It was registered in August 2015, but not found anymore on Açu lagoon (see Table 1).

Medeiros et al. (2006) suggests that $P$. trihamatus most likely would be driven to Amazon River, on Brazilian north region, regarding to local marine currents. However, we registered this species on the southeastern region, which do not excludes dispersion route suggested by that author, but reveals new alternatives for natural dispersion (Havel and Shurin, 2004) and/or introduction (Dibacco et al., 2012) from north to south of Brazilian territory. It is also possible an unregistered occurrence of this species between Rio de Janeiro and Pernambuco, southernmost region of its occurrence until now (Santos et al., 2009), considering that plankton diversity is not well studied along Bahia and Espírito Santo states. In addition, some studies discuss the possible independent introductions from Asia to different parts of Brazil of this non-native species (Medeiros et al., 2006; Santos et al., 2009). Table 2 shows an updated scenario of $P$. trihamatus distribution along Brazilian coast.

Açu lagoon is under influence of fishing and livestock activities, is located on a Harbor Industrial District and has history of shrimp farming on a nearby lagoon (Salgada) during the 60's (unpublished data). Therefore, the complexity of this environment makes it difficult to identify the exact route of $P$. trihamatus introduction. The presence of this species is diagnostic of the vulnerability of this environment. Therefore continued monitoring of its presence and possible establishment in Açu lagoon 
and also in Brazilian southeastern region is required for a better understanding of its ecological relation with native species and implications for the local biological community.
As far as we know, morphological difference observed on $P$. trihamatus female sampled was not described in any other paper. This difference may be a punctual individual anomaly or a taxonomic feature from an isolated
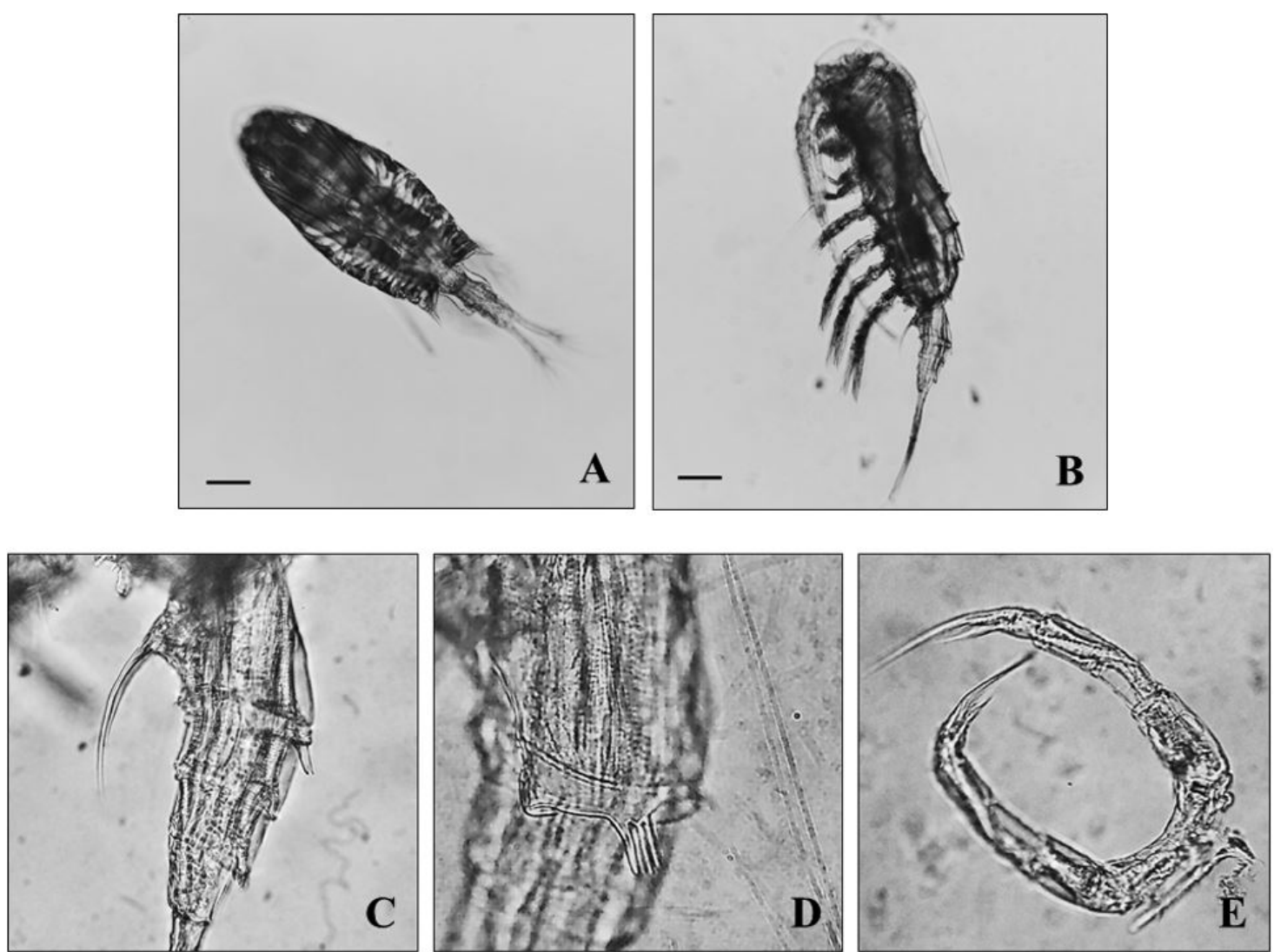

Figure 1. Pseudodiaptomus trihamatus female general view and taxonomic features. (A) dorsal view; (B) lateral view; (C) two long spines on the genital somite ventral portion; (D) three spines on the genital somite left posterodorsal portion; and (E) fifth leg.
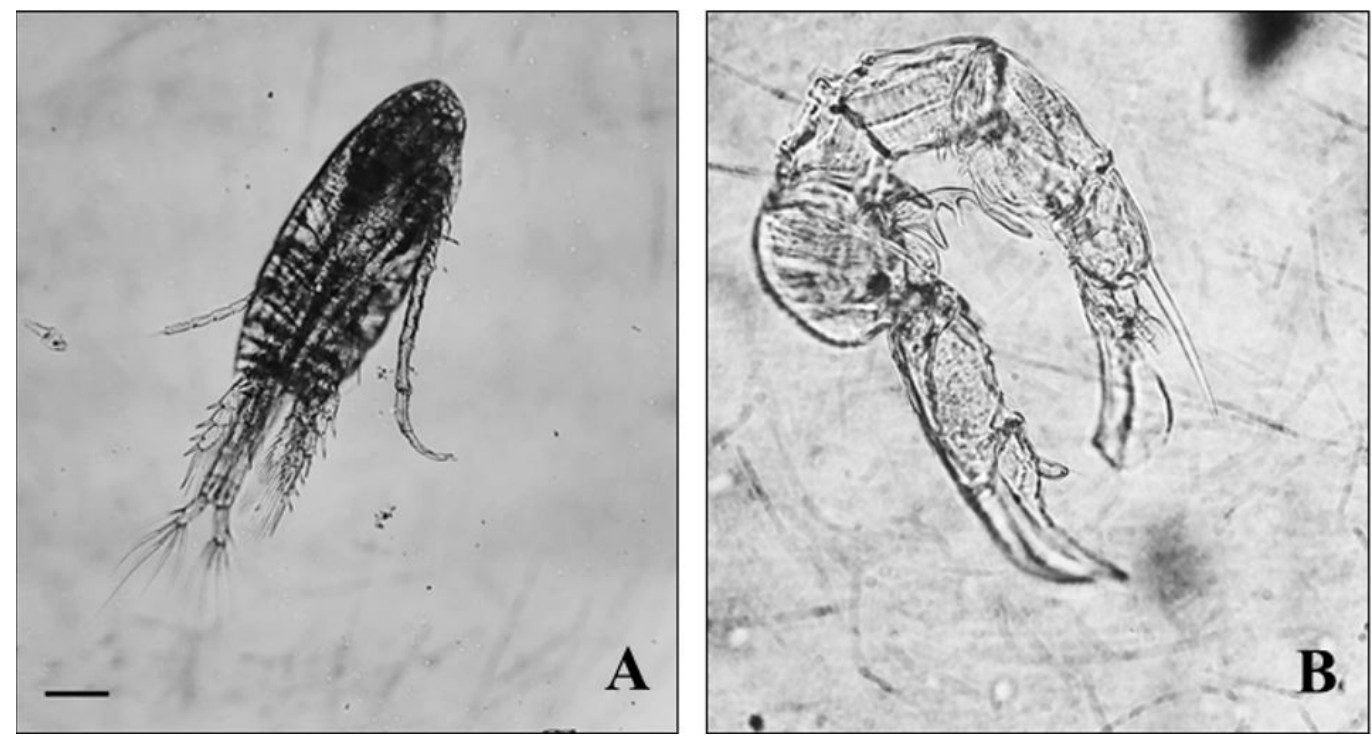

Figure 2. Pseudodiaptomus trihamatus male general view and taxonomic features. (A) dorsal view; and (B) fifth leg. 
Table 1. Density (ind. $/ \mathrm{m}^{3}$ ) of Pseudodiaptomus species at Açu Lagoon (coordinates: $21^{\circ} 55^{\prime}$ ' and $22^{\circ} 00^{\prime} \mathrm{S}$; $40^{\circ} 57^{\prime}$ and $\left.41^{\circ} 00^{\prime} \mathrm{W}\right)$ with its respective salinity.

\begin{tabular}{ccccc}
\hline Period & $\begin{array}{c}\text { Pseudodiaptomus spp } \\
\text { (copepodito) }\end{array}$ & P. acutus & P. trihamatus & Salinity (\%o) \\
\hline May/14 & 0 & 0 & 0 & 13.59 \\
July/14 & 0 & 0 & 0 & 13.57 \\
January/15 & 0 & 0 & 0 & 14.14 \\
March/15 & 0 & 0 & 0 & 16.83 \\
April/15 & 0 & 0 & 0 & 27.03 \\
July /15 & 0 & 0 & 0 & 19.33 \\
August/15 & 0 & 700 & 0 & 25.49 \\
September/15 & 200 & 0 & 0 & 74.00 \\
October/15 & 120 & 0 & 10 & 28.49 \\
November/15 & 0 & 0 & 0 & 32.07 \\
December/15 & 0 & 0 & 0 & 30.81 \\
January /16 & 0 & 0 & 0 & 31.39 \\
February/16 & 0 & 0 & 0 & 31.82 \\
March /16 & 0 & 0 & 0 & 38.00 \\
\hline
\end{tabular}

Table 2. Information from environments where Pseudodisptomus trihamatus was registered in Brazil.

\begin{tabular}{|c|c|c|c|c|c|}
\hline Reference & $\begin{array}{c}\text { Collected } \\
\text { year }\end{array}$ & State & $\begin{array}{c}\text { Salinity } \\
(\%)\end{array}$ & Environment & $\begin{array}{c}\text { Density } \\
(\text { Ind./m }\end{array}$ \\
\hline Medeiros et al. (1991) & 1977 & Rio Grande do Norte & ---- & Potengí Riv & $\begin{array}{ll}--- \\
---\end{array}$ \\
\hline Medeiros et al. (2006) & $2001-2005$ & $\begin{array}{l}\text { Rio Grande do Norte } \\
\text { and Ceará }\end{array}$ & $18-70$ & Estuarine and coastal waters & ---- \\
\hline Santos et al. (2009) & 2006 & Pernambuco & $6.5-9.9$ & Pina Basin & $0.14-1.29$ \\
\hline Almeida et al. (2012) & 2005 & Rio Grande do Norte & $36-38$ & $\begin{array}{l}\text { Guaraíras Lagoon (Costal } \\
\text { lagoon) }\end{array}$ & 10 \\
\hline This papper & 2015 & Rio de Janeiro & $13.6-74$ & Açu Lagoon (Costal lagoon) & 10 \\
\hline
\end{tabular}

population in southeastern Brazil. Continuous surveys on Açu lagoon gathering adequate number of specimens and also molecular studies involving different populations could help with further conclusions (Achinelly et al., 2016). Genetic distance could also elucidate the closest related populations helping understand the source of this introduction (Miglietta et al., 2015).

\section{References}

ACHINELLY, M.F., ELICECHE, D.P., BELAICH, M.N. and GHIRINGHELLI, P.D., 2016. Variability study of entomopathogenic nematode populations (Heterorhabditidae) from Argentina. Brazilian Journal of Biology $=$ Revista Brasileira de Biologia, vol. 77, no. 3, pp. 569-579. http://dx.doi.org/10.1590/1519-6984.20015. PMid:27783765.

ALMEIDA, L.R.D., COSTA, I.S. and ESKINAZI-SANT'ANNA, E.M., 2012. Composition and abundance of zooplankton community of an impacted estuarine lagoon in Northeast Brazil. Brazilian Journal of Biology $=$ Revista Brasileira de Biologia, vol. 72, no. 1 , pp. 12-24. http://dx.doi.org/10.1590/S1519-69842012000100002. PMid:22437380

CHAGAS, G.G. and SUZUKI, M.S., 2005. Seasonal hydrochemical variation in a tropical coastal lagoon (Açu Lagoon, Brazil). Brazilian Journal of Biology $=$ Revista Brasileira de Biologia, vol. 65, no. 4, pp. 597-607. http://dx.doi.org/10.1590/S151969842005000400006. PMid:16532183.

CORDELL, J.R., BOLLENS, S.M., DRAHEIM, R. and SYTSMA, M., 2008. Asian copepods on the move: recent invasions in the Columbia-Snake River system, USA. Journal du Conseil, vol. 65, no. 5, pp. 753-758. http://dx.doi.org/10.1093/icesjms/fsm195.

DIBACCO, C., HUMPHREY, D.B., NASMITH, L.E. and LEVINGS, C.D., 2012. Ballast water transport of non-indigenous zooplankton to Canadian ports. Journal du Conseil, vol. 69, no. 3, pp. 483-491. http://dx.doi.org/10.1093/icesjms/fsr133.

FERREIRA, C.E.L., JUNQUEIRA, A.D.O.R., VILLAC, M.C. and LOPES, R.M., 2009. Marine bioinvasions in the Brazilian coast: brief report on history of events, vectors, ecology, impacts and management of non-indigenous species. In: G. RILOV and J.A. CROOKS, eds. Biological invasions in marine ecosystems. Berlin: Springer, pp. 459-477. http://dx.doi.org/10.1007/978-3540-79236-9 27.

HAVEL, J.E. and SHURIN, J.B., 2004. Mechanisms, effects, and scales of dispersal in freshwater zooplankton. Limnology and Oceanography, vol. 49, no. 4, pp. 1229-1238. http://dx.doi. org/10.4319/10.2004.49.4_part_2.1229.

MATSUMURA-TUNDISI, T. and TUNDISI, J.G., 2007. Occurrence of Pseudodiaptomus gracilis (F. Dahl, 1894), Copepoda, Calanoida in amazonian fresh waters. Brazilian Journal of Biology $=$ Revista Brasileira de Biologia, vol. 67, no. 3, pp. 
585-586. http://dx.doi.org/10.1590/S1519-69842007000300029. PMid:18094847.

MEDEIROS, G.F., MEDEIROS, L.S., HENRIQUES, D.M., CARLOS, M.T., FAUSTINO, G.V.B.D.S. and LOPES, R.M., 2006. Current distribution of the exotic copepod Pseudodiaptomus trihamatus Wright, 1937 along the northeastern coast of Brazil. Brazilian Journal of Oceanography, vol. 54, no. 4, pp. 241-245. http://dx.doi.org/10.1590/S1679-87592006000300008.

MEDEIROS, G.F., ROCHA, C.E.F. and SILVA, M.L., 1991. A note on the occurrence of Pseudodiaptomus trihamatus Wright, 1937 (Crustacea: Copepoda) in Natal, Brazil. Boletim of the Department of Oceanography and Limnology, vol. 8, pp. 113.

MIGLIETTA, M.P., ODEGARD, D., FAURE, B. and FAUCCI, A., 2015. Barcoding Techniques Help Tracking the Evolutionary History of the Introduced Species Pennaria disticha (Hydrozoa, Cnidaria). PLoS One, vol. 10, no. 12, pp. e0144762. http://dx.doi. org/10.1371/journal.pone.0144762. PMid:26657561.

OKA, S., SAISHO, T. and HIROTA, R., 1991. Pseudodiaptomus (Crustacea, Copepoda) in the brackish waters of mangrove regions in the Nansei Islands, southwestern Japan. Nihon Seibutsu Chiri Gakkai Kaiho, vol. 46, pp. 83-88.
SANTOS, D.A., GARCIA-DIAZ, X.F., GUSMÃO, L.M.O. and SCHWAMBORN, R., 2009. Registro do Copepoda exótico Pseudodiaptomus trihamatus Wright, 1937 no estado de Pernambuco (Brasil). Revista Brasileira de Engenharia de Pesca, vol. 4, no. 1, pp. 124-133.

STERZA, J.M., SUZUKI, M.S. and TAOUIL, A., 2002. Resposta do zooplâncton a adição de nutrients inorgânicos ( $\mathrm{N}$ e P) em mesocosmos na lagoa do Açu, Campos dos Goytacazes/ São João da Barra, RJ. Acta Limnologica Brasiliensia, vol. 14, no. 2, pp. 87-94.

WALTER, T.C., 1984. New species of Pseudodiaptomus from the Indo-Pacific, with a clarification of $P$. aurivilli and $P$. mertoni (Crustacea: Copepoda: Calanoida). Proceedings of the Biological Society of Washington, vol. 97, no. 2, pp. 369-391.

WALTER, T.C., OHTSUKA, S. and CASTILLO, L.V., 2006. A new species of Pseudodiaptomus (Crustacea: Copepoda: Calanoida) from the Philippines, with a key to pseudodiaptomids from the Philippines and comments on the status of the genus Schmackeria. Proceedings of the Biological Society of Washington, vol. 119, no. 2, pp. 202-221. http://dx.doi.org/10.2988/0006-324X(2006) 119[202:ANSOPC]2.0.CO;2. 